The level of training provided to these employees was minimal. It was felt that the reason for hiring them was to get work out of them in the short run, not to mold them into excellent workers. They were provided with a brief description of how books are arranged according to the Library of Congress system, given a short test to ensure their comprehension of this, and then turned loose on the shelving. Later on, they were given some additional instructions to learn how to shelf read. Daily supervision and work assignments became the responsibility of the Stacks Supervisor, a full-time clerical staff person.

Manpower displayed an interest in the performance of their people. After the first week an evaluation form was sent for each person. Factors upon which the employees were evaluated included attendance, work habits, and appearance. Because of the short duration of this project, it was necessary to make quick judgments about whether or not each of the employees was going to be adequate. One of the employees had to be fired after the third day due to an attendance problem. Manpower was notified about the problem, and sent a replacement the next day.

The results of this experiment were satisfactory. The shelving was done quickly and in time for the start of second semester. A portion of the collection was shelf read. Manpower was able to supply the library with competent employees on very short notice. The most significant problem was that towards the end of the project several of the workers had to quit to go back to school. By this time Manpower's labor pool had dwindled so they were not able to provide replacements.

The overall level of ability and effort displayed by the Manpower employees was on a par with that of the student assistants who work in the library. The cost was somewhat higher than it would have been to hire student assistants, but as there were not enough student assistants available, the point is moot. The use of temporary employees in lieu of student assistants will certainly be considered in the future for tasks such as shelving, shelfreading or shifting.

\title{
Humor and creativity: Music
}

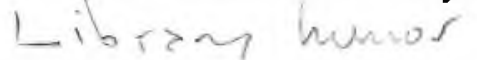

\section{By Norman D. Stevens}

\section{Director}

The Molesworth Institute
The many examples of library humor that I have collected over a number of years, including the many recent examples contributed by readers of these columns, demonstrate that music librarians, as I have long suspected for other reasons, are among the most creative and the most peculiar of all librarians. Perhaps I can now, at last, reveal that fact since I have recently been appointed, upon payment of the usual fee, Conductor of $\mathrm{Li}$ braries In Absentia at the North American School for the Artsy and Somewhat Musically Inclined in White Bear Lake, Minnesota.

The true reasons for this phenomenon remain a mystery but we can freely speculate about those reasons. It may be that, as sometimes frustrated and sometimes practicing musicians, music librarians share the creative traits associated with musicians and other artists that give them a broader imaginative scope than other librarians. Whoever heard of a funny chemist or chemistry librarian? Part of that creativity, of course, may be associated - as I will demonstrate below - with the right brain/left brain concept. Music librarians, so to speak, have a foot in both camps. Perhaps it may also be that their isolation from the mainstream of librarianship, and often from contact with other librarians on their own campus, as they work in remote and isolated branch libraries, drives them stir crazy or unleashes their imagination. Whatever the reason, it is clear that there is a great deal of entertainment to be found in their humor that deserves to be shared with a wider audience and not confined, as it so often has been, to their own kind.

In an earlier column on holidays (November 1988) I commented on the 1976 performance of The Salutation Army Band at the University of Illinois Library as a minor, and tame, example of music and library humor that involved both commentary and performance. That was, indeed, a mild case.

Bad puns seem to be among the most frequent themes of bad music library humor. That is exemplified by what were originally hand-lettered signs, which have now been replaced by more permanent professional signs, on the five listening rooms in the Greer Music Library at Connecticut College. Those rooms are named: John's Cage; The Nutcracker Suite; The Liszt-ning Room; The Haydn Place; and The Bach Room. Still, those puns seem harmless in comparison with those re- 
ported by Harold E. Samuel as allegedly having been found on the walls of the men's room in the Music Library at Yale University. As noted in the MLA Notes 3 (June 1977): 970-71, those included: "He's Offenbach in three minutes"; "Get Orff my Bach"; and "Can you Handel it?" That epic contribution was followed in short order by two contributions (MLA Notes 34 (March 1978): 758, and 35 (September 1978): 199) consisting entirely of obscure stories built around puns on composer's names ("I got poison Ives when a Wolf chased me into a brio Partch"). It is now even possible to purchase from the Library of Congress a small canvas bag with a picture of Bach and the inscription, "Bach's Lunch." And C\&RL News readers may remember the photo of Ohio State University Music Library's "Johann Suggestion Box" in the June 1982 issue, with the editor's accompanying caption, "Sonata Bad Idea."

Another favorite vehicle for humor in the music library is the creation of imaginary individualsmost often composers - perhaps modeled on the lucrative career of Peter Schickele's P.D.Q. Bach. That genre is best represented by Johann Nepomuk Krank (1886-1965) whose career is honored through regular exhibits on the anniversary of his birth (April 1) and death (November 19) created by Peter Munstedt at the Conservatory Library at the University of Missouri, Kansas City. Those exhibits have included strange photos of the Krank Memorial Museum and Library and the adjacent Krank Archives in Smellberg, Pennsylvania, that houses the jumbled manuscript of his infamous treatise, "Stretto in the Ghetto." Other exhibits have featured his later career as music director at Our Lady of the Night Convent in Billings, Montana, and his rarely performed "Organ Concerto for Three Hands."

The varied, if somewhat limited, range of music library humor is best demonstrated though, through a careful examination of Cum Notis Variorum, the newsletter of the Music Library of the University of California at Berkeley. Under the able editorship of Ann P. Basart, that widely distributed and always read newsletter features humorous pieces on a regular basis often under the aegis of Skillin Q. Fowlstrunker (S.Q.F.) who may well be a relative of Johann Nepomunk Krank and P.D.Q. Bach.

Puns are, of course, a staple of that newsletter, as in an imaginary account of the explosion of $\mathrm{Mt}$. Saint Helens ( $\# 44$, July/August 1980) that described it as "like a Fauré inferno charring every Field in sight and producing a real Kreisler for the whole area." A similar view of the world was expressed in the proud report (\#73, June 1983) that the Music Library was doing its part in response to the Reverend Jerry Falwell's call for more "moral" books in libraries by stocking works by Pablo del Moral and José Zorrila y Moral among others. Earlier, in fact, (\#61, April 1982) the editor had commented on the existing holdings of the Music Li- brary in response to Phyllis Schaffly's call for libraries to acquire pro-defense ("War Songs and Poems of the Southern Confederacy"), pro-family ("The Berio Family Album"), pro-basic education ("Basic Musicianship"), and pro-life (isn't that what music is all about?) materials.

Cum Notis Variorum also periodically holds contests on subjects that produce such delightful results (\#104, July 1986) as exam answer howlers ("Gesamtkunstwerk: something you say when someone sneezes"), reference questions ("Do you have Nightmares? [a rock group]"), silly titles of musical works ("Missa Circumcisionis"), the everpopular unintentionally funny Library of Congress subject headings ("Waltzing mice. See Dancing mice."), and earlier (\#101, April 1986) poetry primarily in the form of higgelty-piggelties (double dactyls) based on the names of musicians ("Bippityboppity / Mendelssohn-Bartholdy's / Not really known by his / Multi-part name. / Music librarians / Add it when typing to / Overauthenticate. / Have they no shame?").

The creation of the "Little Grove," or The Smith College Dictionary of Music and Musicians (\#103, June 1986) featured the definition of musicology as "A science that is concerned with all fields and problems of music except music itself" and described Sibelius as a "Finnish composer who is so Finnish that one can hardly find the Finnish melody in his work."

Often going beyond the strict bounds of music librarianship, S.Q.F. has sometimes addressed such issues as how to locate periodical articles in any large academic library. His twenty-six step opus

\section{Feeling funny?}

The stern admonition in my January column-or was it simply the fact that I was commenting on the ubiquitous staff newsletter?-brought a generous response and many excellent new examples of library humor. My thanks to all who have contributed material. My regrets to all who have neglected to inform me of the wonderful things they are doing in this arena. Although I may have almost exhausted the scope of academic library humor, there are still a few themes that I want to touch on before I give you a respite and leave you to your own devices. Library poetry has been dribbling in, but so much of it is execrable that more examples worth publishing are badly needed. Creative anecdotes and stories are also sought. Tales of the staff refrigerator and pencil sharpeners, along with those of other mundane library equipment, remain high on my want list. As usual, please send that information, or other humorous material, to me at 143 Hanks Hill Road in Storrs, CT 06268 along with your business card, and those of your colleagues, signed and dated on the verso. 
(\#88, December 1984) on that task featured such challenges as "look for another fiche reader in which the bulb has not burned out" and "climb five flights of stairs thinking of it as exercise." His world-famous treatise on "The Storage and Care of Librarians" was cited in an earlier column (April 1989). For all they have done to promote the cause of library humor, Cum Notis Variorum, Skillin Q. Fowlstrunker, and Ann P. Basart deserve special commendation.

The final example of humor from the music library is from a short series on the place, and placement, of the pencil sharpener in libraries that appeared in The Lantern's Core, from the Northwestern University Library in 1972. The final contribution in that multi-part series from Stephen Fry on "A Music Library Pencil Sharp- ener" (December 13, 1972) confirms part of my initial hypothesis that the right brain/left brain syndrome may be behind the deviant nature of humor in the music library. His note describes a gray Apsco "Giant" type III-A sharpener and the problems encountered in providing effective access to it when new stacks were added. The ultimate solution was to "rotate the sharpener base 180 degrees (along an East-West axis), and then rotate the pencil shavings compartment, which holds the rotary head, 180 degrees (along a North-South axis)....It is now especially handy for left-handed people [Fry noted].... and this seems to be a great drawing feature of our library.... We invite left-handed people who cannot elsewhere find suitable machines to sharpen their pencils at the Music Library."

\title{
A library-sponsored tutorial program
}

\author{
By Susan Deese
}

Director, Center for Academic Program Support

University of New Mexico

The Center for Academic Program Support (CAPS), a comprehensive tutorial center, has been a department within the University of New Mexico General Library since 1980. The program, originally called the Skills Center, was established in 1979 as the academic support unit of a comprehensive remedial program. During 1979-1980, the Center was housed in the library but was not part of the library administratively. Funding was provided through an instructional budget from the Office of the Provost.

Since that time, the Center has expanded its support services to provide assistance to all undergraduate students and to graduate students enrolled in selected statistics courses. Credit library courses are offered through the Center. Library 110 is a two-credit course in learning skills which emphasizes the relationship between traditional study skills and learning theory. Library 111 is a twocredit course in library skills which emphasizes a search strategy approach to the use of library tools. Library 112 is a one-credit course in which students combine skills from Library 111 with paperwriting skills to produce a research paper.

The director of the Center is the only member of the library faculty who does not have a Master of Library Science degree. The director's terminal degree is a Doctor of Philosophy in Adult Education. When the director completed the Ph.D. in 1984 , the library faculty members voted to accept the di- rector into the faculty. Until that time, the director had been a member of the administrative staff reporting to the assistant dean for public services but had not been a member of the library faculty. Currently, the Center director is a member of the Council of Department Heads which serves as the library management team.

Funds for the program are provided to the library in a separate instructional budget from the Office of the vice president for academic affairs (formerly the Office of the Provost). In 1985 the undergraduate student leaders decided to terminate their attempts at sponsoring a tutorial program and decided to allocate student fees to the Center for the purpose of providing assistance to all undergraduates. In 1988 the leaders of the Graduate Student Association voted to allocate funds to the Center for the purpose of providing tutorial assistance to graduate students enrolled in selected graduate level statistics courses.

More than 5,000 students (approximately onethird of the undergraduate population) came to the Center during 1987-1988. More than 19,500 contacts were made with those students for a total of approximately 13,000 contact hours (actual amount of time spent by students at the Center). In addition to the director, the staff includes an associate director, an assistant director, a coordinator of special programs, an administrative secretary, a weekend and evening supervisor, and approxi- 